\title{
The Ijaws (IZONS) Of The Niger Delta Region And Political Agitations In Nigeria: Past And Present
}

\author{
Adangor Z. \\ PhD (Aberdeen), BL., MCIArb; Associate Professor, \\ Department of Public Law, Faculty of Law, \\ Rivers State University, Port Harcourt
}

\begin{abstract}
The Ijaws (Izons) are the largest ethnic group in the Niger Delta Region of Nigeria and the $4^{\text {th }}$ largest in the federation. However, within the context of Nigeria's ethnic structure dominated by three majority ethnic groups of Hausa/ Fulani, Yoruba, and Igbo respectively, the Ijaws rank amongst ethnic minorities and have been victims of ethnic domination and marginalization in all spheres of the Nigerian society. The domination of the Ijaws which clearly negates the core value of Nigerian federalism that no one ethnic group should suffer domination or be dominated by other groups, has instilled in them the spirit of political agitation in their quest for equity, fairness and justice amongst over 250 ethnic groups comprised in the Federation of Nigeria. This paper analyses the political experience of the Ijaws in Nigeria's multi-ethnic Federation and their agitations for emancipation from the claws of internal colonialism. As a culturally distinct ethnic group, the Ijaws insist that the structure of the Nigerian federal State stymies their capacities to develop at their own pace according to the natural resource endowment and fiscal potentials of their region. It is argued that the current over-centralisation of power and resources as a means of holding the country together cannot guarantee the stability of the Nigerian State unless the constituent units are granted sufficient space for self-expression. The agitations of the Ijaws will likely continue into the future until the Federation of Nigeria is restructured to eschew the domination of ethnic minorities including the Ijaws by their ethnic majorities. Given that the Report of 2014 National Constitutional Conference addresses the questions of ethnic domination and participation of the constituent states in natural resource governance, it is recommended that the Buhari administration should take steps to transmit the Report to the National Assembly for necessary legislative action. This paper adopts analytical research methodology and relies on primary and secondary materials.
\end{abstract}

KEYWORDS: Ijaw ethnic group, Niger delta, Nigeria.

\section{INTRODUCTION}

The Federal system in Nigeria is multi-ethnic and has evolved through a process of disaggregation of the original unitary state known as the Colony and Protectorate of Nigeria into constituent regions to which power was progressively dispersed. Unlike the federal arrangements in national federations such as the United States of America (USA), Switzerland and Australia which were largely influenced by economic and military considerations and the desire to build larger polities, the federal system in Nigeria was designed to recognise, accommodate, empower and reconcile the disparate ethno-cultural groups within her geographic territory so as to achieve unity in diversity. ${ }^{1}$ Unarguably, as a 'holding-together'

\footnotetext{
1 Alfred Stepan, 'Federalism and democracy: Beyond the U. S. model' (1999) 10 Journal of Democracy 19, $20-21$. Nathan Glazer, 'Federalism and ethnicity: The experience of the United States' (1977) Publius: The Journal of Federalism 71, 72-73; Rotimi Suberu, 'Federalism in Africa: The Nigerian experience in comparative perspective' (2009) 8 Ethnopolitics 67, 71.
} 
federation, Nigeria's federalism forms a solidarity couple with ethnicity and the divisive forces associated with ethnicity cannot be wished away.

Nigeria's multi-ethnic federation comprises no less than 250 distinct ethnic groups made up of three majority ethnic groups of Hausa/Fulani, Yoruba and Igbo and about 247 minority ethnic groups across northern and southern regions. Prior to the colonization of the political territory now called Nigeria, these disparate ethnic nationalities had existed as independent, separate and distinct entities, each exercising sovereignty within its own territory and managing its own affairs without any interference from the others. ${ }^{2}$ Although evidence of interactions amongst these disparate ethnic groups exist prior to colonization, the groups perceived themselves as fundamentally different from each other and their relationships were characterised by mutual suspicion and mistrust ${ }^{3}$.

It was these disparate ethnic groups that the British imperial power through a staggered process which commenced effectively on August 6, 1861 with the execution of the Treaty of Cession of Lagos, subjugated, conquered and forcefully brought together to form a single political entity called the Colony and Protectorate of Nigeria with the amalgamation of the Protectorate of Northern Nigeria and the Colony and Protectorate of Southern Nigeria on January $1,1914^{4}$. The amalgamation itself, which was recommended to the Colonial Office by the Niger Committee headed by Lord Selborne (1898) and executed by Britain without any input from the ethnic groups directly affected by it, was never designed to create a united country. On the contrary, its overriding consideration was the administrative convenience of using "funds available from the richer 'South' to offset the adverse financial standing of the less prosperous 'North' and so reduce fiscal dependence on scarce imperial grants-in-aid"5.

The result of the unholy marriage celebrated by the British imperial power between Southern and Northern Nigeria was the creation of a country made up of "nations and peoples who had no reason to think of themselves as members of a common society." 6 Thus, Nigeria has remained largely a gathering of ethnic groups forcefully brought together by Britain without any unifying force. ${ }^{7}$ To put baldly, the ethnocultural diversity of the peoples of Nigeria and the artificiality of the Nigerian state have interplayed in varying degrees to produce a strong sense of ethnic consciousness and identity amongst the peoples of Nigeria with each ethnic group scrambling for access to scare resources and political power at the centre and waging a perpetual war of survival against the rest. In this ending scramble for power and scarce resources, ethnicity plays a major role.

${ }^{2}$ A-G Federation v. A-G Abia State (No. 2) [2002] 6 NWLR (Part 764) 542, 670-671; see also Biodun Adediran, "The origins of Nigerian peoples" in Richard Olaniyan (ed), Nigerian History and Culture (Longman Group Limited, Essex 1985)10; ${ }^{2}$ Federal Ministry of Information, "Nigerian Peoples and Their Cultures" $(2016)<$ http://www. fmi.gov.ng/ about-nigeria/history-people/\#tabs-127-0-1>accessed 25 September, 2017; Central Intelligence Agency, "The World Fact-book" (2016)<http://www.cia.gov/library/ publications/the-worldfactbook/geos/ni.html> accessed 25 September, 2017.

${ }^{3}$ Elizabeth Isichei, A History of Nigeria (Longman Group Ltd. Essex 1983) 4.

${ }^{4}$ See the Nigeria Protectorate Order-in-Council, 1913; Lord Milverton, "Nigeria" (1948) 47 African Affairs 80, 81.

5 Tekena N. Tamuno, "Nigerian Federalism in Historical Perspective" in Kunle Amuwo, Adigun Agbaje, Rotimi Suberu, et al, Federalism and Political Restructuring in Nigeria (Spectrum Books Limited, Ibadan 1998) 13, 15; F. D. Lugard, 'Report on the amalgamation of Northern and Southern Nigeria, and administration, 1912-1919' (Cmnd. 468 London, 1920) para. 5.

6 B. R. Rubin and J. B. Asuni, 'Transition, a new opportunity to transform Nigeria's numerous conflicts' in M. Mekenkamp et al. (eds), Searching for Peace in Africa: An overview of Conflict Prevention and Management Activities (European Platform for Conflict Prevention and Transformation/ African Centre for the Constructive Resolution of Disputes, Utrecht 1999)332.

7 Obafemi Awolowo, The People's Republic (OUP, Ibadan 1968) 69. 
It is within the context of the realities of ethnic politics in Nigeria that this paper seeks to analyse the political experience and struggle of the Ijaws (Izons) in the Niger Delta region of Nigeria with a view to identifying factors that militate against their liberation from the bondage of internal colonialism.

This paper is divided into six sections. The introductory part captures the background to the research and its focus. The second section provides a brief survey of the Ijaws within the context of Nigerian multi-ethnic federation. In sections three and four, the paper discusses the agitations and struggle of the Ijaws for political survival in pre-colonial and colonial Nigeria. The fifth section examines the political experience of the Ijaws in post-colonial Nigeria and the lessons to be drawn therefrom and the relevance of those lessons in the light of the present realities in the Federation of Nigeria. The concluding remarks are contained in the last part of the paper

\section{A BRIEF SURVEY OF THE IJAW ETHNIC GROUP}

The Ijaws are one of about 250 ethnic nationalities or groups comprised in the Federation of Nigeria and the largest in the Niger Delta region. They are reputed to be the $4^{\text {th }}$ largest ethnic group in Nigeria and have their traditional settlements situate throughout the Niger Delta. ${ }^{8}$ In terms of administrative spread, Ijaw clusters are found in six States out of the existing thirty six States of the Federation. Ijaw clusters are found in Arogbo and Apoi areas of Ondo State in south-west Nigeria. Ijaw minorities also exist in Edo and Akwa-Ibom States while Delta and Rivers States harbour large Ijaw settlements. The largest Ijaw population is found in Bayelsa State which is the only homogenous Ijaw State in the Federation of Nigeria. ${ }^{9}$

Apart from Baysela State, it is indisputable that the Ijaws in the remaining five States of Rivers, Delta, Akwa-Ibom, Ondo and Edo respectively are virtual ethnic minorities. Thus, the only federating State controlled by the Ijaws in the Federation is Bayelsa State. The balkanization of the Ijaws into six States of the Federation in which they constitute ethnic minorities except one has been a major source of grievance amongst the Ijaws who argue that the structure of the Nigerian State is deliberately skewed against them and in favour of the three majority ethnic groups of Hausa/Fulani, Yoruba and Igbo.

In terms of Local Government Areas (LGAs), the Ijaws have not fared any better because out of the current 774 local government areas in Nigeria, the Ijaws dominate only 24, namely Bayelsa (8), Rivers (9), Delta (4), Ondo (1); and Akwa Ibom (2). For instance, the local government areas dominated by the Ijaws in Rivers State out of the current 23 LGAs are namely; Andoni, Asari-Toru, Akuku-Toru, Bonny, Degema, Ogu/Bolo, Okrika; and Opobo/Nkoro. However, Ijaw communities are also found in Port Harcourt City Local Government Area, Abua/Odual and Ahoada East LGAs. ${ }^{10}$

Unarguably, the total number of LGAs dominated by the Ijaws is far lower than that controlled by the Hausa/Fulani in Kano State alone which has 44 LGAs or Katsina State that has 33

\footnotetext{
${ }^{8}$ Central Intelligence Agency, "The World Factbook" (22 August 2013)<

http://www.ciagov/library/publications/the-world-factbook/geo/nihtml> accessed March 5, 2018; Obafemi Awolowo, Thoughts on Nigerian Constitution (OUP, Ibadan 1966) 24

9 Tekena N. Tamuno, Oil Wars in the Niger Delta 1849-2009 (Stirling-Horden Publishers Ltd., Ibadan 2011) 17; Kimse Okoko "Restructuring Nigeria: Position of the Ijaw Nation" The Guardian (Tuesday February 22, 2005) 118, 119; E.J. Allagoa, The Ijaw Nation in the New Millennium (Onyoma Research Publications, Port Harcourt, 1999 ) 9.

10 See First Schedule, Part I, to the Constitution of the Federal Republic of Nigeria, 1999 (as mended).
} 
LGAs. ${ }^{11}$ It is submitted therefore, that although admittedly, the Ijaws are the $4^{\text {th }}$ largest ethnic group in Nigeria, the truth of the matter is that they belong to the rank of ethnic minorities.

In the context of Nigerian ethnic politics, "ethnic minorities" are groups which do not belong to any of the three majority ethnic groups of Hausa/Fulani, Yoruba and Igbo. However, in a functional sense, the classification of ethnic minorities must take into consideration not only distinct cultural identity and comparative demographic strength, but also socio-political and economic standing of the groups measured in terms of their level of participation in the political and economic affairs of the federation. From this perspective, ethnic minorities are historically, linguistically, culturally, and territorially distinct groups which by reason of their comparatively small demographic size, have been subjected "to subordinate political, social and economic positions in the federation and its constituents units." 12

Arguably, the Ijaws of the Niger Delta are ethnic minorities in the functional sense defined above because of their continued domination and oppression in the political, economic, cultural, and social spheres in the federation. Although the immediate president of Nigeria, Goodluck Jonathan, is of Ijaw extraction, it would be naïve to suppose that the Jonathan presidency had changed the classification of the Ijaws as ethnic minorities in the functional sense of the term. Two terms of Jonathan presidency would not have been enough to effectively liberate the Ijaw ethnic nationality from the claws of internal colonialism because of the entrenched hegemony of the three majority ethnic groups.

The structure of the Nigerian state from inception gives a decided advantage to the majority ethnic groups in the acrimonious competition for political power and distribution of federallycontrolled resources. The most compelling manifestation of the superordinate-subordinate relations between the majority ethnic groups and the ethnic minorities during Nigeria's First Republic was in the regional political structures. Each region was dominated by a major political party with strong ethnic character led by a political leader representing the dominant ethnic group. Thus, the Hausa/Fulani controlled the Northern People's Congress (NPC) in Northern Region, the Yoruba dominated the Action Group (AG) in Western Region and the Igbo controlled the National Council of Nigerian Citizens (NCNC) in Eastern Region. While Ahmadu Bello (Hausa/Fulani) led the NPC, Obafemi Awolowo (Yoruba) headed the AG leaving Nnamdi Azikiwe (Igbo) to take charge of the NCNC. With this ethno-regional tripodal political structure erected on the demographic superiority of the Hausa/Fulani, Yoruba and Igbo respectively, the domination and of ethnic minorities was complete. ${ }^{13}$

More disturbingly, the British colonial government held the irrepressible but misleading notion that 'Nigeria falls naturally into three regions, the North, the West and the East', ${ }^{14}$ each dominated by the Hausa/Fulani, Yoruba and Igbo, respectively. The implication of this official

11 See First Schedule, Part I to the 1999 Constitution.

12 Eghosa E. Osaghae, 'Managing Multiple Minority Problems in a Divided Society: The Nigerian Experience' (1998)

136 Journal of Modern African Studies 1, 3-4.

13 Abdul Raufu Mustapha, 'Ethnic structure, inequality and governance of the public sector in Nigeria' (Democracy, Governance and Human Rights Programme Paper No. 24: United Nations Research Institute for Social Development, Geneva November 2006) 5; John P. Mackintosh, 'Federalism in Nigeria' (1962) X Political Studies 223, 233-234.

14 Secretary of State for the Colonies, 'Despatch from the governor of Nigeria to the Secretary of State for the Colonies' (Cmnd. 6599 London, 1945) para. 3;

para. 3; 19. Tekena N. Tamuno, Oil Wars in the Niger Delta 1849-2009 (Stirling Horden Publishers Ltd, Ibadan 2011) 4 . 
position of the colonial government was that ethnic minorities, including the Ijaws in the Niger Delta had to be subsumed politically under the three dominant ethnic groups, rather than been granted separate administrative units to protect and safeguard their interests.

Contrary to the views expressed by Kirk-Greene ${ }^{15}$ and Hale ${ }^{16}$ that the creation of more states in Nigeria has significantly reduced the spectre of domination of ethnic minorities by the majorities, the truth of the matter is that state creation has not minimized the domination of the Niger Delta minorities including the Ijaws. The persistence of the agitation by ethnic minorities for restructuring the federation in spite of the numerous state creation exercises dating back to 1967, attests to the fact that state creation is not the panacea for ethnic domination and marginalization.

To be sure, out of the current 36 federating states, the three majority ethnic groups dominate 24 states representing 67 percent while the northern and southern minorities dominate the remaining 12 states representing 33 percent of the total. ${ }^{17}$ Thus, a coalition between two of the three dominant groups is sufficient to guarantee them perpetual control of the central government including power over natural resources. Although by virtue of section 48 of the Constitution of the Federal Republic of Nigeria, 1999 (as amended), each state of the federation has equal representation in the Senate while representation in the House of Representatives varies according to the population of each state in accordance with section 49 of the Constitution, it is beyond any dispute that since the three majority groups have majority of the states in the federation, their representatives in both chambers of the National Assembly enjoy numerical superiority over those representing the ethnic minorities.

It follows inexorably that by the application of the majoritarian principle enshrined in section $56(1)$ \& (2) of the 1999 Constitution, a mere coalition between representatives from two of the three dominant ethnic groups is sufficient to push through or defeat any proposal in the National Assembly that the majority groups either desire or oppose. Thus, as far as legislative matters within the competence of the National Assembly are concerned which, the dominance of the majority ethnic groups is unquestionable. Put differently, no matter how many states are created for the Hausa/Fulani, Yoruba and Igbo, each of these ethnic groups will continue to think and vote as single block on major issues affecting their interest as was experienced during the debate on the Petroleum Industry Bill 2012 in the National Assembly. ${ }^{18}$

In the next sub-section, the political experience of the Ijaws before and after political independence and the strategies they have employed in fighting domination will be examined. The relevance of the strategies employed by the Ijaws in the acrimonious competition for political space amongst the disparate ethnic groups in the federation of Nigeria will also be addressed.

\footnotetext{
15 A.H.M. Kirk-Greene, 'The genesis of the Nigerian civil war and the theory of fear' Research Report No. 27 (The Scandinavian Institute of African Studies, Uppsala 1975)2.

${ }^{16}$ Henry E. Hale, 'Divided we stand: Institutional sources of ethnofederal state survival and collapse' (2004) 56 World Politics 165, 189.

17 Ladipo Adamolekun, 'The Nigerian federation at the crossroads: The way forward' (2005) 35 Publius: The Journal of Federalism 383, 399.

18 'Why we oppose petroleum industry bill-northern senators' Vanguard (Lagos, January 1, 2013)<http://www.vanguardngr.com/2013/01/why-we-oppose-petroleum-industry-bill-northernsenators/>accessed December 1, 2017.
} 


\section{IJAWS' POLITICAL AGITATIONS IN PRE-COLONIAL NIGERIA}

According to Alagoa, the Ijaw nation is "one engaged in struggle over all the millennia of its settlement in this difficult, environment, comparable in many ways to the desert terrain in the far northern extremities of Nigeria." 19 Alagoa notes that the hostile environment of the Niger Delta has "nurtured a hardy race" although the "forms of struggle continue to change with time as the antagonists and protagonists also change with time." 20 History has never recorded the Ijaw as a weak nation of fisher-folks, farmers, canoe carvers, gin brewers, traders, entrepreneurs, and politicians. On the contrary, at every stage of their political journey, the Ijaw nation had shown resilience, strength and inexhaustible capacity to confront the enemy, whether the enemy was the European or Portuguese traders or the neo-colonialists within Nigeria.

As an ethnic group privileged to have had early contacts and commercial dealings with White traders on the West African Coast, the Ijaws fought gallantly to protect and secure their lucrative position as middlemen between the White traders and palm oil suppliers and slave dealers in the hinterland. Although the superior military power of the British army subdued several traditional rulers and potentates of the Ijaw nation on the coast into signing the purported "treaties of protection" with Her Britannic Majesty, the Ijaws gave the British a good fight in the quest of the latter to colonize the blocks of territory that later became Nigeria. ${ }^{21}$

Traditional Rulers such as King William Dappa Pepple (Perekule V) of Bonny (1835-1866), King Frederick William Koko (Mingi VIII) of Nembe (1889-1898), King Jaja of Opobo, and King Ibanichuka of Okrika at different times, challenged the juridical foundation of the power and authority of Her Britannic Majesty to interfere in the internal affairs of the several coastal Ijaw city-states. ${ }^{22}$ The encounter between these Ijaw Monarchs, amongst others and the colonial authority serves to demonstrate the resilience of the Ijaw spirit and their capacity to conquer.

\section{THE IJAWS IN COLONIAL NIGERIA: THE PRE-INDEPENDENCE ERA}

Following the amalgamation of Southern and Northern protectorates in 1914, the British colonial administration coerced the several Ijaw city-states into becoming members of the new Nigerian State without any form of prior consultation because as noted earlier, the amalgamation of 1914 that produced Nigeria was conceived, designed and executed by the British without any reference to the diverse ethnic groups directly affected by it. ${ }^{23}$ The apex Ijaw socio-cultural organization, the Ijaw National Congress (INC), has rightly described Ijaw membership of the Nigerian State as an "involuntary journey" that has robbed the Izons of their sovereignty as a people. ${ }^{24}$

The Nigerian State which emerged from the amalgamation of 1914 soon proved to be highly oppressive of ethnic minorities. The spectre of ethnic domination became aggravated with the introduction of regionalism under the Richard's Constitution, 1946 because the structure of

\footnotetext{
19 Allagoa (n9) 7.

${ }^{20}$ Allagoa (n9) 7-8.

${ }^{21}$ See for example, Treaty with King and Chiefs of New Calabar dated July 4, 1884; Treaty with the King and Chiefs of River Bonny dated 3rd October 1950; Additional Articles to the Commercial Treaty with Bonny dated 23rd January 1854; Treaty with the Kings and Chiefs of Brass, dated 17th November 1856 and others numbering over 30 contained in Hertslet's Commercial Treaties Vol. XVII (Henry Butterworth London 1827-1925) 130 - 159.

22 Tamuno (n14) 43-58

23 Sir Bernard Bourdillan and Richard Palmer, "Nigerian Constitutional Proposals" (1945) African Affairs 120, 123 $-4$

${ }^{24}$ Ijaw National Congress, The Ijaws, the Niger Delta and the Nigerian State (University of Port Harcourt Press, Port Harcourt 2006) 7.
} 
each regional government and the leadership of the dominant political party in each region were surrendered to the three majority ethnic groups of Hausa/Fulani, Yoruba and Igbo. To be sure, regionalism itself, was driven by the misleading notion by the British colonialists that "Nigeria falls naturally into three regions; namely the North, the West and the East." 25 These three "natural regions of Nigeria" according to the colonial view, coincided with the Hausa/Fulani (North), Yoruba (West) and Igbo (East) thus, reducing the remaining over 247 ethnic groups including the Ijaws to junior partners in the Nigerian project and facilitating their domination by the majority groups.

As agitations for Nigeria's political independence thickened, the Ijaws feared that the attainment of independence from Britain would herald a new form of internal colonialism by the three majority ethnic groups. Against this background, the Ijaws and other non-Igbo ethnic groups of Calabar and Ogoja demanded from the British colonial government the protection of their rights to self-determination in a politically independent Nigeria through the creation of separate states that would cater for their interest. ${ }^{26}$ These agitations led to the setting up of Henry Willink Commission of Enquiry by the colonial government "to ascertain the facts about the fears of minorities in any part of Nigeria and to propose means of allaying those fears whether well or ill-founded." 27

Although the Commission in its final report rejected the demands for creation of new states to cater for the interest of ethnic minorities, it recommended that the Rivers Province should be considered as a "special area" and that a Federal Board be established to direct the development of the region into channels which would meet its peculiar needs. The Commission also recommended the inclusion of the Bill of Rights in the Constitution of Nigeria for the protection of all Nigerians. ${ }^{28}$

Perhaps, the greatest benefit of the pre-independence agitations by the Ijaws was the establishment of the Niger Delta Development Board (NDDB) pursuant to s.159 of the 1963 Constitution. Other development agencies such as the Niger Delta River Basin Authority (1976), Oil Minerals Producing Areas Development Commission (1992), and the Niger Delta Development Commission (2000) have been established as successors to the NDDB to address the special development needs of the Niger Delta region.

It must be noted, however, that beyond the establishment of the NDDB, the pre-independence agitations did not mitigate the domination of the Ijaws by the ethnic majorities. Even in the area of infrastructural development, the conditions of the Ijaw communities have not improved significantly because contrary to the observation of the Willink's Commission that a federal government-driven development option (top-bottom approach) was unsuitable for the region, the federal government has continued to direct, supervise and manipulate all development

\footnotetext{
25 Secretary of States for the Colonies (n14) para. 3.

${ }^{26}$ See A Resolution, re Rivers State by the Conference of Rivers Chiefs and People adopted on Wednesday September 12th 1956, reproduced in A. Etekpe, Y. Ayotamuno, U. G. Nwala, et. al, Harold Dappa-Briye: His contributions to Politics in Nigeria (Onyoma Research Publications, Port Harcourt 2004) 185-192; Ben Naanen, 'State Movements' in E. J. Alagoa and A. A. Derefaka (eds), The Land and People of Rivers State: Eastern Niger Delta (Onyoma Research Publications, Port Harcourt 2002) 339, 340-346.

27 Secretary of State for the Colonies, 'Report of the Commission Appointed to Enquire into the Fears of Minorities and the Means of Allaying Them' (Cmnd. 505, London 1958) (hereinafter cited as “Willink's Report”).

28 Willink's Report (n27) paras. 103-105; The Willink's Commission had observed that "We agree that it is not easy for a Government or a legislature operating from far inland to concern itself, or even fully to understand, the problems of a territory where communications are so difficult, building so expensive and education so scarcity"; see para 15 of the Report.
} 
agencies established for the Niger Delta region. The result is that the Niger Delta has remained 'poor, backward and neglected" today as it was in 1958 when the Willink's Commission used those catchy words to describe its backwardness.

\section{THE IJAWS IN POST-INDEPENDENT NIGERIA}

The Ijaw membership of the Nigerian State has not been beneficial to her people in spite of their enormous contributions that the Niger Delta region has made to the sustenance and stability of the federation. This ugly situation has resulted directly from the hegemonic control of the apparatus of the central government by the ethnic majorities. It will be recalled that the primary consideration for the formation of Nigerian federation was that no ethnic group or region should gain domination over the others and none should suffer domination from another. Charles R. Nixon stated the matter well thus:

One of the underlying premises of the Nigerian thought had been that the condition of association in the federal system was that no region would gain domination over the others and no region need suffer domination from another. The fear of domination had been the primary consideration in the shaping of the federal system. ${ }^{29}$

Another scholar, Schwarz, has also noted that the federal system in Nigeria was "intended to provide a guarantee that no one tribe could easily dominate the rest." ${ }^{30}$ Nigerian federalism, therefore, was designed to prevent the domination of one ethnic group by another whether in the political, social, economic or cultural sphere. Ethnic domination in all its ramifications is therefore, incompatible with the core value of Nigerian federalism. Another underlying principle of Nigerian federalism is that the constituent units of the federation should be encouraged to develop at their varying speed along their characteristic lines. ${ }^{31}$ Each region or constituent state was to be encouraged and empowered to develop its natural resources and enhance its fiscal capacity so as to able to drive its own development programmes without being dependent on a distant central government.

The question that arises, therefore, is whether the underlying principles of Nigerian federalism have been actualized whether generally or in relation to the Ijaw ethnic minorities? The answer is obviously in the negative! The Ijaw ethnic nationality has been the constant victim of domination by the three majority ethnic groups of Hausa/Fulani, Yoruba and Igbo in terms of the right of participation in the political, economic, social, and cultural spheres of the country.

In the economic sphere, for instance, the Ijaw land produces crude oil which has remained the mainstay of Nigeria's economy since the 1970's but the Ijaws do not benefit from the exploration and production activities that take place within their territory. By the conspiracy among the three majority ethnic groups, the natural resources in Ijaw land were nationalised through obnoxious laws and expropriated by the federal government. The result is that minerals, mineral oils and natural gas located in the Niger Delta region or in any other part of the Federation are vested in the federal government. ${ }^{32}$ The expropriation of the natural resources of the Ijaws of the Niger Delta has now been constitutionalised by the provision of

${ }^{29}$ Charles R. Nixon, "Self-Determination: The Nigeria/Biafra Case” (1972) 24 World Politics 473, 479.

30Walter Schwartz, Nigeria (Pall Mall Press, London 1968) 15.

31 Nigeria, No. 464A, Official Despatch from the Colonial Office (July 15, 1950) 3.

32 See generally, Petroleum Act, 1969, section 1(1) \& (2) Cap. P10 LFN 2004 as amended by the Petroleum (Amendment) Act No. 23 of 1996; Exclusive Economic Zone, Act Cap. E17, LFN 2004; Territorial Waters Act 1967, Cap.T5 LFN 2004; Offshore Oil Revenue Decree 1971, Oil Pipelines Act 1965, Cap.07 LFN 2004; Interpretation Act, Cap.123 LFN 2004;Land Use Act 1978, Cap. L5 LFN 2004. 
section s. 44(3) of the Constitution of the Federal Republic of Nigeria 1999 (as amended) which provides that:
s. 44 (3) Notwithstanding the foregoing provisions of this section, the entire property in and control of all minerals, mineral oils and natural gas in, under or upon any land in Nigeria or in, under or upon the territorial waters and the Exclusive Economic Zone of Nigeria shall vest in the Government of the Federation and shall be managed in such manner as may be prescribed by the National Assembly. ${ }^{33}$

In relation to offshore petroleum resources, the Supreme Court of Nigeria has held in $A-G$ Federation v. A-G Abia State (No. 2),34 that based on the extant statutory provisions and the combined provisions of the Geneva Convention on the Territorial Sea and the Contiguous Zone 1958, Geneva Convention on the Continental Shelf 1958 and the United Nations Convention on the Law of the Sea 1982, sovereignty over offshore petroleum resources vest in the federal government of Nigeria to the exclusion of the federating states. Thus, petroleum resources including natural gas located offshore within Nigeria's territorial waters, exclusive economic zone and continental shelf are regarded as located within the territory of the Federation of Nigeria and outside the geographical territory of the federating states. It was further held by the Supreme Court that revenue which accrues to the federation account from offshore petroleum operations belongs to the entire Federation of Nigeria and not to the defendants' littoral oil-producing states for the purpose of the application of the principle of derivation pursuant to s.162 (2) of the 1999 Constitution. ${ }^{35}$

Therefore, the position of the law in Nigeria is that no state of the federation, local government council, ethnic group, person or group of persons other than the federal government has any right of ownership or power of governance over natural resources. To be sure, the power conferred on the federal government under the 1999 Constitution over natural resources is total and complete as it combines both proprietary rights with right of governance and management of petroleum resources.

Deriving from the vesting of ownership rights over natural resources exclusively in the federal government is the fact that only the federal government has the sole authority to grant oil rights and mineral titles to third parties to explore, prospect for and exploit the nation's vast natural resources subject to prescribed terms and conditions. Furthermore, the power to raise revenue from the exploration and exploitation of Nigeria's petroleum and mineral resources under the different contractual arrangements also vests in the federal government. The 1999 Constitution (as amended) assigns export duties and the taxation of incomes, profits and capital gains (except as otherwise prescribed by the Constitution) to the National Assembly thus enabling the federal government to exercise fiscal power both in terms of legislation and administration over the petroleum sector. ${ }^{36}$ The fiscal power of the federal government over

\footnotetext{
${ }^{33}$ Cap. C23, Laws of the Federation of Nigeria 2004 (hereinafter '1999 Constitution' ); s. 44(3) of the 1999 Constitution re-enacts section $40(3)$ of the repealed Constitution of the Federal Republic of Nigeria 1979.

34 [2002] 6 NWLR (Part 764) 542, 828-9.

35 The negative impact of this judgment on the revenue base of the littoral oil-producing States has been minimised with the enactment of the Allocation of Revenue (Abolition of the Dichotomy in the Application of the Principle of Derivation) Act 2004 which provides for the application of the principle of derivation to off-shore petroleum resources extracted within 200 metre water depth Isobath contiguous to a State of the federation. The same Supreme Court upheld the constitutionality of this Act in A-G Adamawa v. A-G Federation [2005] 18 N. W. L. R. (Pt. 958) 581, 673-4 on the ground that the Act merely provides for the application of the derivation principle to natural resources extracted within the specified maritime zone rather than granting ownership or control over those resources to the oil-producing states.

${ }^{36}$ See item nos. 25 and 59 in the exclusive legislative list.
} 
the oil and gas sector as prescribed in other enabling laws covers fees, ${ }^{37}$ rents, ${ }^{38}$ royalties, ${ }^{39}$ petroleum profit tax, ${ }^{40}$ penalties, bonuses, and crude oil sale receipts, etc.

Clearly, centralization of natural resource has become a veritable tool of domination by the majority ethnic groups against oil-producing Ijaw communities of the Niger Delta. Armed with political and economic powers, the bulk of the oil wealth produced from the Ijaw territory of the Niger Delta has "captured by the federal state and distributed to the so-called 'ethnic majorities' in the politically dominant northern and western states." ${ }^{41}$ Through this oppressive employment of their demographic, political and economic superiority, resources have been transferred from the Niger Delta to establish industries, build federal government institutions and develop key infrastructure in the dominant regions while leaving behind a neglected and weak periphery. It is within this context that the criminal neglect of the Niger Delta by successive federal administrations in spite of decades of exploitation of hydrocarbons by the Nigerian State can have real meaning.

Unarguably, the infrastructural backwardness of Ijaw communities of the Niger Delta and the abysmal poverty of the Ijaws in spite of decades of petroleum production from their homeland are simply part of the orchestrated marginalization that has become scandalous features of Nigerian ethnic politics. The entrenched marginalization of the Ijaws also accounts for the failure of the federal government to address the ecological and environmental externalities associated with oil and gas production in the Niger Delta region which have completely crippled the traditional economy of the region and affected the quality of lives of its peoples. ${ }^{42}$

The Ijaw environment has continued to suffer from horrendous pollution and degradation associated with oil and gas exploration and exploitation. Apart from the lack of an effective environmental regulatory mechanism, there is also lack of political will by the central government to enforce extant regulations, particularly whenever the international oil companies (IOCs) are involved. The result is that the Niger Delta has been rendered far more vulnerable to the adverse impacts of petroleum exploration and exploitation than most other oil producing regions in the world.

A 2006 study carried out by an independent team of experts drawn from Nigeria, the UK and the US has found that the Niger Delta (the homeland of the Ijaws) is 'one of the 5 most severely petroleum damaged ecosystems in the world' and that the devastation of the region 'may even be worse than other notoriously impacted regions such as Azerbaijan, Kazakhstan, Siberia, and Ecuador' ${ }^{43}$ The report describes the environmental damage to the Niger Delta as 'chronic and cumulative' and that it has acted,

\footnotetext{
37 Petroleum Act, ss.3(3) and 4(4); Oil Pipeline Act, s. 7(2) and s. 31; Petroleum Regulations, regulation 58; Nigerian Minerals and Mining Act, ss.55, 61(j) and 70(m).

38 Petroleum Regulations, regulation 60, paras.1 and 2.

39 Petroleum Regulations, regulation 61 para.1 (i)-(vii).

40 Petroleum Profits Tax Act, cap.P13, L. F. N. 2004, s.8.

41 Michael Watts, 'Crude politics: Life and death on the Nigerian oil fields' Niger Delta Economies of Violence Working Paper No. 25 (Institute of International Studies University of California Berkeley USA, 2009) 18 <http://oldweb.geog.berkeley.edu/ProjectsResource/ND\%20Website/NigerDelta/WP/Watts_25.pdf/>accesse d December 12, 2017.

42 Ibibia Lucky Worika, 'Deprivation, despoilation and destitution: Whither environment and human rights in Nigeria's Niger delta?' (2001-2002) 8 ILSA J. Int'l \& Comp. L. 1, 5.

43 Federal Ministry of Environment et al, 'Niger Delta natural resource damage assessment and restoration project, phase 1-scoping report' (Abuja, 2006) 3.
} 
Synergistically with other sources of environmental stress to result in a severely impaired coastal ecosystem and compromised the livelihoods and health of the region's impoverished residents. ${ }^{44}$

A learned scholar has therefore rightly concluded that more than five decades of oil exploration and exploitation in the Niger delta have merely produced "three Ds" in Ijaw land, namely "deprivation, despoliation and destitution." 45

The structure of the Nigerian federation, particularly in terms of the regional distribution of federating units has also ensured the domination of the Ijaw nation. The Ijaws were excluded from main-stream governance from 1960 up until April, 2007, when for the first time in Nigerian history, Goodluck Jonathan, an Ijaw, was elected Vice President and later in 2011, became the elected president. Prior to this period, the Ijaws had played second fiddle to other ethnic groups in spite of the huge sacrifices they made towards defending and preserving the territorial integrity of the country during the Nigeria-Biafra Civil War. The Ijaw ethnic nationality has also suffered unprovoked massive military assault and bombardments which led to the complete destruction of two of her communities, namely Odi and Ayakoromo.

To be sure, the Ijaw ethnic nationality has never accepted the unfair, oppressive and discriminatory treatment meted out to her by the Nigerian State without protest. From the traditional rulers who protested against undue British interference in trade on the West African coast during colonial rule, to the political leaders who championed the Ijaw cause during the period just before independence and Isaac Adaka Boro, who launched the 12 day revolution and declared the "Delta Peoples' Republic" in 1966, Ijaw people have consistently and uncompromisingly agitated for fairness and equity in the governance of Nigeria. Through the resource control agitations championed by various Ijaw socio-cultural organizations notable amongst which were the Ijaw National Congress (INC) and Ijaw Youths' Congress (IYC), the Ijaws have been unwavering in their agitation for restructuring the Nigerian federation by deconcentrating power at the centre and creating sufficient space for selfexpression by the various ethnic groups. ${ }^{46}$

At the end of its conference in 2005, the South-South Peoples' Assembly (SSPA) adopted a comprehensive 13-point Agenda which called for true federalism, resource control, power rotation and distribution, environmental justice, etc. ${ }^{47}$ Some of these demands were articulated at the failed National Political Reform Conference, 2005 during which the South-South delegation staged the historic walk-out when their agitation for upward review of the derivation principle was rebuffed by delegations from the dominant regions of the federation. The National Constitutional Conference, 2014 also witnessed a robust restatement of the Ijaw position on equity, fairness, resource control, and environmental justice. ${ }^{48}$

Arguably, the consistent position taken by the Ijaw ethnic nationality on restructuring the Nigerian Federation to enthrone fairness and equity since the 1950s has drawn sympathetic attention to the Ijaw cause from other regions of the federation. It is indisputable that the election of President Goodluck Jonathan in 2011 would not have been possible but for the sympathetic response to the Ijaw cause demonstrated by other ethnic nationalities. A calm

\footnotetext{
44 Federal Ministry of Environment (n43) 2.

45 Worika (n41).

46 Okoko (n9).

${ }^{48}$ See Report of the National Constitutional Conference (Abuja, 2014).
} 
reading of the political events in the country at the material time suggested very strongly that the seeming consensus amongst most Nigerians was that the Ijaws should be integrated into Nigerian mainstream politics in order to guarantee peace in the restive Niger delta and thereby secure in favour of the federal government an unimpeded access to the vast hydrocarbons in the region.

Some key lessons could be drawn from the measure of success the Ijaw ethnic nationality has achieved from their agitation for a restructured Federation of Nigeria founded on justice, equity and equality of all component units:

1. That the collective strength of the Ijaws is best harnessed when they work together as a people. This is not to say that every Ijaw son and daughter must key into the Ijaw project, but it is rather to say that as many Ijaws as possible must strive to be part of the Ijaw struggle.

2. That the Nigerian State will not freely concede any right or privilege to the Ijaws ethnic nationality without agitation and mobilization. Therefore, the Ijaw agitations for restructuring the federation, for resource control and for environmental justice must be sustained and the strategies in pursuit of these goals must constantly reflect the realities of the time.

3. That in order to succeed in their quest for enthronement of a fair and equitable political arrangement in Nigeria, the Ijaws need to build bridges of friendship, co-operation and collaboration not only across the River Niger but also with other ethnic groups within the Niger Delta

4. That the Ijaw ethnic nationality must strive to identify credible men and woman in the various communities who possess the requisite capacities to champion the Ijaw cause within the context of Nigerian ethnic politics and who could be entrusted with responsibilities both at state and federal levels.

\section{THE IJAWS AND THE PRESENT POLITICAL REALITIES IN NIGERIA}

There is no doubt that the Jonathan's presidency marked a watershed in the Ijaw's struggle for fairness, equity and justice in the Nigerian project. It was the culmination of decades of struggle for a new Nigeria where every ethnic group whether majority or minority, will enjoy the same rights and privileges and where none will suffer domination. Arguably, the election of President Jonathan reaffirmed the faith of the Ijaw in the unity and indissolubility of the Federation of Nigeria because it offered the most compelling evidence of Ijaw freedom from the shackles of ethnic domination and their acceptance into the mainstream of Nigerian politics.

However, the point must be made that as soothing and reassuring as Jonathan's presidency must have been to the Ijaws, it did not address nor solve the core of the Ijaw agitations over the decades which is resource control. The Ijaws insist that each constituent state of the federation should own and manage the natural resources located within its geographic territory and pay appropriate taxes to the centre. This unwavering position taken by the Ijaws is underscored by the fact that prior to the discovery of crude oil in the Niger Delta in 1956, the old regional governments controlled by the three majority ethnic groups, had controlled the natural resources located within their respective territories or least, received $100 \%$ derivation from the centre. Furthermore, the Jeremy Raisman's Fiscal Commission set up by the British colonial government few years before the grant of political independence to Nigeria had recommended that: 
Whenever a profit sharing arrangement is negotiated in Nigeria between the Federal Government and an oil company, the Federal Government should consider the desirability of associating other governments within the Federation as parties to it. ${ }^{49}$

Perhaps motivated by his determination to address some of these burning national issues, President Jonathan inaugurated the National Constitutional Conference on March 21, 2014 "to engage in intense introspection about the political and socio-economic challenges confronting our nation and to chart the best and most acceptable way for the resolution of such challenges in the collective interest of all the constituent parts of our fatherland." 50

The National Conference submitted its report in which it made far-reaching recommendations. For instance, on the question of protection of ethnic minorities against domination, it recommended that all executive and strategic positions in all tiers of government rotate among all the zones or states or ethnic nations making up Nigeria or senatorial districts or local governments making up a state or wards making up a local government in order to attain equity and justice for all constituent units. ${ }^{51}$ With respect to the question of resource control by the oil-producing states or ethnic groups, the conference recommended that mines and minerals, including oil fields, oil mining and geological surveys and natural gas should continue to be retained as legislative items on the exclusive legislative list provided that the governments of states where the mining activities take place shall be involved in matters relating thereto and that the federal government shall create a special fund for the development of mines and minerals in states where such resources are undeveloped. 52

Owing to some inexplicable reasons, the Jonathan administration could not transmit the Conference Report to the National Assembly for necessary legislative action before the 2015 general elections in which president Jonathan conceded defeat. Most Nigerians had expected that the current Buhari administration would give serious attention to the Report of the 2014 Constitutional Conference by transmitting same to the National Assembly for necessary legislative action.

Unfortunately, the signals coming from the presidency point to the contrary because President Buhari has been quoted as reportedly saying that he wanted the report of the 2014 national conference to go into the archives where it belonged. ${ }^{53}$ Besides, the northern delegates to the 2014 national conference under the aegis of the Northern Delegates Forum had issued a communique questioning the legal validity of the report of the conference and calling on members of the National Assembly not to rely or act on the report. ${ }^{54}$ Thus, it would appear that the core northern Nigeria, which is the biggest beneficiary of Nigeria's current centralized federal system, is averse to the implementation of the report and this in spite of the fact that

\footnotetext{
${ }^{49}$ Secretary of State for the Colonies, 'Nigeria: Report of the Fiscal Commission' (Cmnd. 481, London 1958) para.109.

50 "Photonews: President Jonathan Inaugurates National Conference" Sahara Reporters (March 17, 2014)http://saharareporters.com/2014/03/17/photonews-president-jonathan-inaugurates-nationalconference/ >accessed June 25, 2017.

51 See Report of National Constitutional Conference (2014) 121.

52 Report of National Constitutional Conference (n102) 138.

${ }^{53}$ Henry Umoru \& Levinus Nwabughiogu, "Buhari: Confab report is for the archives" Vanguard (June 4, 2016)http://www.vanguardngr.com/2016/06/buhari-confab-report-is-for-the-archives/ >accessed June 27, 2017.

54 Saawua Terzungwe, "Northern delegates reject Jonathan's confab report" Daily Trust (April 13, 2017)https://www.dailytrust.com.ng/northern-delegates-reject-jonathans-confabreport/193367.htm/>accessed June 27, 2017
} 
the conference itself was headed by the Justice Kutigi, former Chief Justice of Nigeria, who hails from the north and that virtually all the recommendations of the conference were arrived at by consensus.

The challenge confronting Ijaw ethnic nationality, therefore, is how to prevail on the federal government to implement the report of the 2014 National Constitutional Conference. In this regard, the Ijaws must work collaboratively and co-operatively with other ethnic groups both within and outside the Niger Delta to ensure implementation of the said report. The Ijaws must be prepared to build symbiotic political relationship and alliances with other neighbouring ethnic groups even within the Niger Delta region in order to achieve set goals. As an ethnic minority group, there is little the Ijaws could achieve on their own without working in collaboration with other ethnic groups, particularly those in the south-south geopolitical zone of the federation. Such cooperation and collaboration between the Ijaws and other ethnic nationalities could provide veritable source of strength to drive their agitations for a restructured Nigeria.

\section{CONCLUDING REMARKS}

The Ijaws have been victims of oppression and domination since pre-colonial Nigeria. Understandably, the Ijaw political experience has been laced with agitations for fairness, equity and justice. In 2011, Nigerians across all geo-political zones identified with the Ijaw cause by voting massively for President Goodluck Jonathan. Although President Jonathan lost the 2015 presidential election gallantly by conceding defeat, his election in 2011 changed the landscape of Nigerian ethnic politics. Given that the Ijaws may not have another opportunity to have one of their own serve at that highest level of political leadership in the immediate near future, they must continue to leverage on that singular opportunity by remaining in mainstream Nigerian politics.

Given their inferior demographic size compared with the ethnic majorities, the Ijaws cannot do without building bridges of friendship, cooperation and collaboration with other ethnic groups both within and outside the south-south geopolitical zone for the purpose of advancing their own cause.

The Report of the 2014 National Constitutional Conference must not be allowed to be consigned to the dustbin of history. That Report advances the Ijaw cause in several ways though not holistically. No effort should be spared in campaigning for its implementation through appropriate legislative action by the National Assembly.

\section{References}

Adamolekun, L., (2005), 'The Nigerian federation at the crossroads: The way forward' 35 Publius: The Journal of Federalism 383.

Adediran,B., (1985), 'The origins of Nigerian peoples' in Olaniyan, R., (ed), Nigerian History and Culture (Longman Group Limited, Essex)10.

A-G Adamawa v. A-G Federation [2005] 18 N. W. L. R. (Pt. 958) 581.

A-G Federation v. A-G Abia State (No. 2) [2002] 6 NWLR (Part 764) 542, 670-671

Allagoa, E. J., (1999), The Ijaw Nation in the New Millennium (Onyoma Research Publications, Port Harcourt).

Allocation of Revenue (Abolition of the Dichotomy in the Application of the Principle of Derivation) Act 2004.

Awolowo, 0., (1966), Thoughts on Nigerian Constitution (OUP, Ibadan).

Awolowo, O., (1968), The People's Republic (OUP, Ibadan).

Bourdillan, B., and Richard Palmer, R., (1945), 'Nigerian Constitutional Proposals' African Affairs 120. 
Central Intelligence Agency, (2016) 'The World Fact-book'<http://www.cia.gov/library/ publications/the-worldfactbook/geos/ni.html> accessed 25 September, 2017.

Constitution of the Federal Republic of Nigeria, 1999 (as amended).

Etekpe, A., Ayotamuno, Y., Nwala, U. G., et.al, (2004), Harold Dappa-Briye: His contributions to Politics in Nigeria (Onyoma Research Publications, Port Harcourt).

Exclusive Economic Zone, Act Cap. E17, LFN 2004.

Federal Ministry of Environment et al, (2006), 'Niger Delta natural resource damage assessment and restoration project, phase 1-scoping report' (Abuja).

Federal Ministry of Information, (2016), 'Nigerian Peoples and Their Cultures'< http://www. fmi.gov.ng/ aboutnigeria/history-people/\#tabs-127-0-1>accessed 25 September, 2017.

Glazer, N., (1977), 'Federalism and ethnicity: The experience of the United States' (1977) Publius: The Journal of Federalism 71, 72-73.

Hale, H. E., (2004), 'Divided we stand: Institutional sources of ethnofederal state survival and collapse' 56 World Politics 165.

Hertslet's Commercial Treaties Vol. XVII (1827-1925), (Henry Butterworth London).

Ijaw National Congress, (2006), The Ijaws, the Niger Delta and the Nigerian State (University of Port Harcourt Press, Port Harcourt).

Interpretation Act, Cap.123 LFN 2004.

Isichei, E., (1983), A History of Nigeria (Longman Group Ltd. Essex).

Kirk-Greene, A. H. M., (1975), 'The genesis of the Nigerian civil war and the theory of fear' Research Report No. 27 (The Scandinavian Institute of African Studies, Uppsala).

Land Use Act 1978, Cap. L5 LFN 2004.

Lugard, F. D., (1920), 'Report on the amalgamation of Northern and Southern Nigeria, and administration, 19121919' (Cmnd. 468 London).

Mackintosh, J. P., (1962), 'Federalism in Nigeria' X Political Studies 223.

Milverton, L., (1948), 'Nigeria' 47 African Affairs 80.

Mustapha, A. R., (2006), 'Ethnic structure, inequality and governance of the public sector in Nigeria' (Democracy, Governance and Human Rights Programme Paper No. 24: United Nations Research Institute for Social Development, Geneva November).

Naanen, B., 'State Movements' in Alagoa E. J., and Derefaka, A. A., (eds), (2002) The Land and People of Rivers State: Eastern Niger Delta (Onyoma Research Publications, Port Harcourt) 339..

National Constitutional Conference (2014), Report of the National Constitutional Conference (Abuja).

Nigeria Protectorate Order-in-Council, 1913.

Nigeria, No. 464A, (1950), Official Despatch from the Colonial Office (July 15).

Nigerian Minerals and Mining Act, 2007.

Nixon, C. R., (1972), 'Self-Determination: The Nigeria/Biafra Case' 24 World Politics 473.

Offshore Oil Revenue Decree 1971.

Oil Pipelines Act 1965, Cap.07 LFN 2004.

Okoko, K., (2005), 'Restructuring Nigeria: Position of the Ijaw Nation' The Guardian (Tuesday February 22,) 118.

Osaghae, E. E., (1998), 'Managing Multiple Minority Problems in a Divided Society: The Nigerian Experience' 136 Journal of Modern African Studies 1.

Petroleum (Amendment) Act No. 23 of 1996.

Petroleum Act, 1969, Cap. P10 LFN 2004.

Petroleum Profits Tax Act, cap.P13, L. F. N. 2004, s.8.

Petroleum Regulations. 
Photonews: President Jonathan Inaugurates National Conference" Sahara Reporters (March 17, 2014)http://saharareporters.com/2014/03/17/photonews-president-jonathan-inaugurates-nationalconference/ >accessed June 25, 2017.

Rubin B. R., and Asuni, J. B., (1999), 'Transition, a new opportunity to transform Nigeria's numerous conflicts' in M. Mekenkamp et al. (eds), Searching for Peace in Africa: An overview of Conflict Prevention and Management Activities (European Platform for Conflict Prevention and Transformation/ African Centre for the Constructive Resolution of Disputes, Utrecht )332.

Schwartz, W., Nigeria (1968), (Pall Mall Press, London).

Secretary of State for the Colonies, (1945), 'Despatch from the governor of Nigeria to the Secretary of State for the Colonies' (Cmnd. 6599 London).

Secretary of State for the Colonies, (1958), 'Nigeria: Report of the Fiscal Commission' (Cmnd. 481, London).

Secretary of State for the Colonies, (1958), 'Report of the Commission Appointed to Enquire into the Fears of Minorities and the Means of Allaying Them' (Cmnd. 505, London).

Stepan, A., (1999), 'Federalism and democracy: Beyond the U. S. model' 10 Journal of Democracy 19.

Suberu, R., (2009), 'Federalism in Africa: The Nigerian experience in comparative perspective' 8 Ethnopolitics 67.

Tamuno, T. N., (1998), 'Nigerian Federalism in Historical Perspective' in Kunle Amuwo, Adigun Agbaje, Rotimi Suberu, et al, Federalism and Political Restructuring in Nigeria (Spectrum Books Limited, Ibadan) 13.

Tamuno, T. N., (2011), Oil Wars in the Niger Delta 1849-2009 (Stirling-Horden Publishers Ltd., Ibadan).

Territorial Waters Act 1967, Cap.T5 LFN 2004.

Terzungwe, S., (2017), “Northern delegates reject Jonathan's confab report” Daily Trust (April

13)<https://www.dailytrust.com.ng/northern-delegates-reject-jonathans-confab-report/193367.htm/>accessed June 27.

Umoru, U., \& Nwabughiogu, L., (2017), 'Buhari: Confab report is for the archives” Vanguard (June 4, 2016)http://www.vanguardngr.com/2016/06/buhari-confab-report-is-for-the-archives/ >accessed June 27.

Watts, M, (2009), 'Crude politics: Life and death on the Nigerian oil fields' Niger Delta Economies of Violence Working Paper No. 25 (Institute of International Studies University of California Berkeley USA).< http://oldweb.geog.berkeley.edu/ProjectsResource/ND\%20Website/NigerDelta/WP/Watts_25.pdf/>accessed December 12, 2017.

Worika, I. L. (2001-2002), 'Deprivation, despoilation and destitution: Whither environment and human rights in Nigeria's Niger delta?' 8 ILSA J. Int'l \& Comp. L. 1. 